\title{
Work schedule influence on sleep habits in elementary and high school teachers according to chronotype
}

\author{
Jane Carla de Souza \\ Sabinne Danielle Galina \\ Jônathas Cleiton Florêncio de Almeida \\ Ivanise Cortez de Sousa \\ Carolina Virginia Macêdo de Azevedo \\ Universidade Federal do Rio Grande do Norte
}

\begin{abstract}
The influence of work schedule on sleep habits and quality, and daytime sleepiness according to individual preferences in sleep schedules was assessed in 131 elementary and high school teachers through questionnaires. Teachers who initiate classes around 7:00 hr wake up earlier and show more frequency of poor sleep quality than those who start classes in the afternoon. Between them, those who have a preference for intermediate or later hours for sleep are more irregular in their wake up schedules and increase their sleep duration on the weekend compared to those with earlier sleep preferences. On the other hand, working only in the afternoon seems to provide better sleep/awake conditions for teachers, because they keep the same sleep duration during the week and on the weekend, and they are diagnosed with less daytime sleepiness. Therefore, the discussion of school start times, originally proposed for adolescents, needs to be magnified to teachers, contributing to improvement of sleep habits and life quality in school environments.
\end{abstract}

Keywords: teacher; chronotype; work schedule; sleepiness, sleep quality.

\section{Resumo}

Influência do horário de trabalho nos hábitos de sono em professores da educação básica de acordo com o cronotipo. A influência do horário de trabalho nos hábitos e qualidade de sono, e sonolência diurna de acordo com preferências individuais nos horários de sono foi avaliada por questionários em 131 professores do ensino básico. Professores que iniciam as aulas \pm 7:00 h acordam mais cedo e apresentam frequentemente sonolência diurna excessiva comparados aos que iniciam à tarde. Dentre estes, àqueles com preferência por horários intermediários ou tardios de sono são mais irregulares nos horários de acordar e aumentam a duração do sono no fim de semana comparados aos professores com preferência por acordar mais cedo. Em contrapartida, trabalhar somente à tarde parece proporcionar melhores condições de sono/vigília, devido não acarretar privação de sono e proporcionar menor frequência de sonolência diurna. Portanto, a discussão do horário de início das escolas originalmente levantada para adolescentes, precisa ser ampliada para professores contribuindo para melhora nos hábitos de sono e qualidade de vida no ambiente escolar.

Palavras chave: professor; cronotipo; horário de trabalho; sonolência, qualidade de sono.

\section{Resumen}

Influencia del horario de trabajo en los hábitos del sueño en maestros de la escuela primaria, secundaria y preparatoria según cronotipo. La influencia del horario de trabajo en los hábitos y la calidad del sueño (dormir) y la somnolencia diurna según cronotipo se evaluó por cuestionarios en 131 maestros. Los maestros que empiezan las clases a las \pm 7:00 h despiertan más temprano y tienen con frecuencia somnolencia diurna en comparación con los maestros que inician las clases por la tarde. Entre ellos, los intermedios y trasnochadores son más irregulares en los horarios de despertar en comparación con los madrugadores. Además, aumentan la duración del sueño el fin de semana. Por otra parte, trabajar solamente por la tarde parece ofrecer mejores condiciones para el sueño y vigilia del maestro, debido no causar privación del sueño y proporcionar menor frecuencia de somnolencia diurna. Por lo tanto, la discusión del horario de inicio de las escuelas originalmente planteadas para los adolescentes, debe ampliarse a los maestros contribuyendo para mejorar los hábitos del sueño y la calidad de vida en la escuela.

Palabras clave: maestros; cronotipo; horario de trabajo; somnolencia, calidad del sueño. 
Environmental (light/dark) and social stimuli (work, scho$\mathrm{ol}$, and feeding) interact exerting influences on the sleep/wake cycle (SWC), advancing or delaying sleep and wake schedules (Mendoza \& Challet, 2009). Among the social stimuli, the school and work schedules exert high influence on the SWC of students and workers, who need to wake up earlier during the week, presenting irregular sleep schedules between the week and the weekend (Groeger, Zijlstra, \& Dijk, 2004; Monk, Buysse, Rose, Hall, \& Kupfer, 2000; Webb, 1985).

This irregularity of the SWC was called 'social jetlag' in analogy to the term 'jetlag,' that traditionally refers to the effect of abrupt changes in sleep and wakefulness as a result of crossing time zones caused by transmeridional trips (Wittmann, Dinich, Merrow, \& Roennenberg, 2006). The uneasiness reported by individuals that have been through transmeridian trips occurs due to the difference between the external time zone and the biological schedule of sleep and wakefulness prior to the trip associated to the transitory state of internal temporal disorganization due to the difference of speeds of adjustment of different rhythms in the body. In the 'social jetlag,' this state chronically occurs in populations of industrialized countries, and is exacerbated in shift-workers, due to the temporal challenge imposed on the body. This pattern of different wake up schedule between weekdays and the weekend was observed in teachers who teach in the morning, however, the effect of chronotype and of different work schedules were not evaluated (Souza, Sousa, Maia, \& Azevedo, 2012a). The chronotype characterizes the person according to their individual preferences by sleep schedules. The morning types (larks) are distinguished by their preference in waking and sleeping earlier when compared to the evening types (owls) who prefer a delayed bedtime, and intermediate types that have an intermediated waking and sleeping schedule (Horne \& Ostberg, 1976).

The irregularity in the SWC is often followed by partial sleep deprivation on weekdays, caused by the conflict between the delayed bedtime and the early wake up time in order to fulfill the social schedule, which leads to negative consequences to health and to individual performance (Dorrian et al., 2008; Gaspar, Moreno, \& Menna-Barreto, 1998; Hansen, Janssen, Schiff, Zee, \& Dubocovich, 2005). Santos-Silva and collaborates (2010) observed an average $7.5 \mathrm{hr}$ of sleep duration in Brazilian adults. Studies performed with Brazilian teachers about working conditions and vocal health found reports a $6.8 \mathrm{hr}$ and $6 \mathrm{hr}$ of sleep duration, however differences between weekdays and the weekend have not been evaluated (Ferreira et al., 2008; Vedovato \& Monteiro, 2008). Similar sleep durations were observed in high school teachers which presented an average of $6.7 \mathrm{hr}$ of sleep duration during the week and an increase of 42 minutes in sleep duration on the weekend, which may be due to partial sleep deprivation on workdays (Souza, Sousa, Belísio, \& Azevedo, 2012b).

Furthermore, the teaching profession faces numerous challenges that can affect their own health and the quality of education, such as: 1.) Long work journey (Decor et al., 2004); 2) lack of time to perform additional tasks related to the te- aching function (correct exams, prepare lessons), which increase the workload (Bauer et al., 2007; Gasparini, Barreto, \& Assunção, 2006); 3) poor teaching conditions (Alves, Robazzi, Marziale, Felippe, Romano, 2009) and 4) increase of violence in schools (Gasparini et al., 2006). All these required obligations cause harm/interference in teachers lives which can result in lack of time for leisure and family (Nagai, Tsuchiya, Toulopoulou, \& Takei, 2007; Penteado \& Pereira, 2007), and may contribute to the emergence of physical (muscle aches, vocal and circulatory problems) and psychological diseases (anxiety, depression, and Burnout Syndrome). All these conditions can contribute to the problems in the organization of sleep-wake cycle, as previously mentioned, that may lead to negative consequences in health and work performance.

Therefore, teachers who have an extensive workload and need to be awake early in the morning due to their work schedule may be experiencing a temporary challenge that can promote partial sleep deprivation and sleep wake irregularity. However, the magnitude of the temporal challenge to fulfill the early morning class can vary according to the chronotype. Morningness is associated to a more increased regularity in sleep duration and schedules (Kitamura et al., 2010), lower sleep latency and daytime sleepiness (Taillard, Philip, \& Bioulac, 1999), and better sleep quality (Kitamura et al., 2010; Soehner, Kennedy, \& Monk, 2011).

The high demand of work of the teachers added to attending to their personal needs can lead this professional to a routine that begins very early in the morning and ends late at night. In this context, the morning types can face smaller challenges fulfilling morning schedules of work and school, but higher difficulty in performing evening/night work. On the other hand, preferences for delayed schedules of sleep and wakefulness observed in the owls can make the challenge of waking up early to go to school or to work even higher when compared to the larks.

Therefore, the aim of this study is to assess the influence of the beginning and ending work schedule on sleep habits and quality, and daytime sleepiness in teachers of the basic education in Natal/BR. Furthermore, to analyze if this influence promotes bigger sleep deprivation and SWC irregularity in the teachers with intermediate and evening chronotypes.

\section{Methods}

\section{Population}

A cross-sectional study was performed with 131 teachers from 30 elementary and high schools in Natal/Brazil (18 public schools and 12 private schools). This study was approved by the Research Ethics Committee of Onofre Lopes Hospital (Protocol $=273 / 08$ ). The data was collected during the academic years from 2009 to 2013, not including vacation and weeks with holidays. This was done to avoid the effects of social events in the sleep patterns of the teachers. 
Initially, there were 562 teachers invited, 425 of them signed the consent form and 349 teachers returned the questionnaires filled out. However, 188 teachers were excluded from the analyses because of incomplete questionnaires or reporting of health problems that compromised the data (insomnia, depression signs or stress). Furthermore, interns or physical education teachers, who usually show different working patterns, and 30 teachers who have irregular work schedules were excluded from the sample. Thus, the final sample was composed of 131 teachers (34 males and 97 females), aged 25 to 59 years old.

\section{Procedures}

The data was collected through questionnaires. On the first meeting, the teachers were told about the objectives and the research method, followed by the signing of the consent form. Those who accepted participating in the research received an envelope with all the questionnaires and the instructions on how to fill them. The questionnaires had to be filled out just once time, but a period of 10 days for the teachers to fill them out was provided and after this period the questionnaires were collected at the school.

The beginning and ending time of work, sleep habits, chronotype, daytime sleepiness, and sleep quality were accessed by the following instruments: 1) In the "Health and Sleep" questionnaire, the teachers report their frequent sleep habits in the last month across the week and weekend, as well the individual characteristics about age, marital status, and work schedule (adapted from Mathias, Sanchez, \& Andrade, 2006). 2) The morningness (lark) and eveningness (owl) questionnaire (Horne \& Ostberg, 1976) adapted for the Brazilian population by Benedito-Silva and collaborators (1990) to access the chronotype. This instrument is composed of 19 questions that measure individual preferences for doing activities in a $24 \mathrm{hr}$ span. The score of this questionnaire characterizes individuals on their chronotypes as morning, evening, or intermediary types. 3) The Epworth Sleepiness Scale (Johns, 1991) is used in clinical cases as much as in research protocols and it measures daytime sleepiness in common situations when the person is more likely to fall asleep. This scale is made up of eight questions each rating 0 to 3 points, with a total score varying from 0 to 24 points. Scores below 10 points indicate low sleepiness levels and scores $\geq 10$ indicate high sleepiness levels. 4) The Pittsburgh Sleep Quality Index (Bussey, Reynolds, Monk, Berman, \& Kupfer, 1989) evaluates sleep quality measuring seven components, scoring from 0 to 3 . The components are: subjective sleep quality, sleep latency, sleep duration, usual sleep efficiency, sleep disorders, consumption of sleeping drugs, and sleep dysfunctions. All the components have a total score from 0 to 21 . The scores between 0 and 5 indicate a good sleep quality and scores above 6 characterize poor sleep quality.

\section{Data analyzes}

For the analysis of the working hours effect on sleep schedule, a cluster analysis was performed that aimed to form homogeneous subgroups from a heterogeneous population. In this study, a k-means cluster analysis was performed using the Euclidean distance measure in order to group the teachers according to the similarities and differences in the beginning and ending time of work. To be included in any group, the teacher should have at least three days of work during the week with the characteristics of one of the groups. The work schedule irregularity was calculated from the standard deviation of beginning and ending work hours reported by the teachers across the weekdays. A One Way Anova was performed to compare the work schedule irregularity and total workload between groups.

The chronotype was categorized in three groups from the distributions of the score in the HO questionnaire. The groups were defined from the first and the third quartiles as limits for the morning and evening tendencies, respectively: 1) morning types, scored between 65 and 76; 2) intermediate types, scored between 50 and 64; and 3) evening types, scored between 27 and 49 .

The sleep habits were analyzed from the wake up and bedtime, the sleep duration, and the irregularity of wake up and bedtimes and sleep duration. The wake up irregularity was obtained from the difference in minutes between the schedules reported by the teachers for waking up on Sunday and during the week (Monday to Friday), whereas the bedtime irregularity was obtained from the difference in minutes between the schedules reported by the teachers for bedtime on Saturday and over the week (Monday to Thursday) The sleep duration irregularity was obtained from the standard deviation of sleep duration in all days of the week (Monday to Thursday, Friday to Saturday, Saturday to Sunday, and Sunday to Monday).

A General Linear Model analysis was used to evaluate the influence of work schedules on the wake up and bedtime, and sleep duration according to chronotype. The working groups created from the cluster analysis and the chronotype were considered as the independent variables, whereas the sleep parameters during weekdays and the weekends were considered as the repeated measures, and the age was considered continuous covariant variables controlled in this analyses. Factorial Anova was performed to compare the irregularity of bed and wake up times during all days of week as well for the sleep duration between groups according to chronotypes. The post-hoc test (LSD Unequal) was applied in all analyses that had a significance level of $5 \%$. There were a few missing data of sleep schedule in all groups.

Chi-square tests with Bonferroni correction were made to evaluate the distribution of the percentage of teachers with respect to the gender, work characteristics, family structure, reported reasons for the bed and wake up times, level of daytime sleepiness, and sleep quality in relation to working groups.

\section{Results}

The cluster analyses created four distinct groups: Morning/Morning $=\mathrm{MM}$ (start $=7: 08 \mathrm{hr} \pm 0: 14 \mathrm{hr}$ and end $=$ $11: 41 \mathrm{hr} \pm 0: 33 \mathrm{hr}) ;$ Morning/Afternoon $=\mathrm{MA}($ start $=7: 16 \mathrm{hr}$ 
\pm 0:36 hr and end $=17: 27 \mathrm{hr} \pm 0: 43 \mathrm{hr}$ ); Afternoon/Afternoon $=\mathrm{AA}$ (start $=13: 05 \mathrm{hr} \pm 0: 15 \mathrm{hr}$ and end $=17: 23 \mathrm{hr} \pm$ 0:09 hr); Morning/Evening $=\mathrm{ME}$ (start $=07: 18 \mathrm{hr} \pm 0: 32 \mathrm{hr}$ and end $=21: 51 \mathrm{hr} \pm 0: 36 \mathrm{hr}$. The schedules of work in each group showed no differences between the days of week, showing a regular schedule (Anova, $p>0.05$ ). The total mean workload did not differ between teachers from the MM (23:55 hr per week) or AA (20:20 hr per week) groups, and the higher workload was observed in the ME group (46:18 hr per week) in relation to the others groups (MA $=40: 09 \mathrm{hr}$ per week $-F_{(3,}$ 127) $=50.70 ; p<0.05$ ).

The majority of teachers from the groups MM, MA, and AA were female, while in the ME group the proportion did not differ between gender (Table 1 ). In all groups, the majority of teachers were married $(\mathrm{MM}=56 \%, \mathrm{MA}=56 \%, \mathrm{AA}=63 \%, \mathrm{ME}$ $=69 \%)$ and have children $(\mathrm{MM}=53 \%, \mathrm{MA}=58 \%, \mathrm{AA}=74 \%$, $\mathrm{ME}=66 \%$ ). The characteristics related to teachers' chronotype and work characteristics are shown in Table 1.

\section{Table 1}

Percentage of Teachers in Relation to Gender, Chronotype, and Work Characteristics According to Work Group

\begin{tabular}{lcccc}
\hline & $\begin{array}{c}\text { MM (n=18) } \\
\%\end{array}$ & $\begin{array}{c}\text { MA ( } \mathbf{n}=\mathbf{5 8}) \\
\%\end{array}$ & $\begin{array}{c}\text { AA (n=19) } \\
\%\end{array}$ & $\begin{array}{c}\text { ME ( } \boldsymbol{n}=\mathbf{3 6}) \\
\%\end{array}$ \\
\hline Gender & $17^{\mathrm{a}}$ & $17^{\mathrm{a}}$ & $6^{\mathrm{a}}$ & $56^{\mathrm{b}}$ \\
Male & 83 & 83 & 94 & 44 \\
Female & & & & \\
\hline Chronotype & $33^{\mathrm{a}}$ & $23^{\mathrm{a}}$ & $32^{\mathrm{a}}$ & $14^{\mathrm{b}}$ \\
Morning type & 45 & 48 & 47 & 56 \\
Intermediated type & 22 & 29 & 21 & 30 \\
Evening type & & & & \\
\hline Type of school & $72^{\mathrm{a}}$ & $43^{\mathrm{b}}$ & $100^{\mathrm{a}}$ & $33^{\mathrm{c}}$ \\
Public & 28 & 41 & 0 & 22 \\
Private & 0 & 16 & 0 & 45 \\
Both & & & & \\
Numbers of school that teaches & $88^{\mathrm{a}}$ & $23^{\mathrm{b}}$ & $95^{\mathrm{a}}$ & $8^{\mathrm{c}}$ \\
One & 6 & 63 & 0 & 47 \\
Two & 6 & 14 & 5 & 45 \\
Three & & & & \\
\hline
\end{tabular}

The teachers who start classes at 7:16 $\pm 0: 27 \mathrm{hr}(\mathrm{MM}, \mathrm{MA}$, ME) wake up about 1:15 \pm 0:45 hr earlier on weekdays (Monday to Friday) when compared to teachers who begin classes at 13:06 \pm 0:15 hr, regardless of chronotype, $F_{(3,115)}=5.95 ; p$ $<0.05$ (Figure 1A). Furthermore, most of the teachers from the MM, MA, ME groups reported the work schedule as the main reason for the time that they wake up and the use of an alarm clock during the week; while the teachers from the AA group reported waking up spontaneously more frequently. The wake up time of the AA group was more associated to domestic chores and extra activities (class preparation - Chi-Square, $p<0.008-$ Figure 3A and 4A).

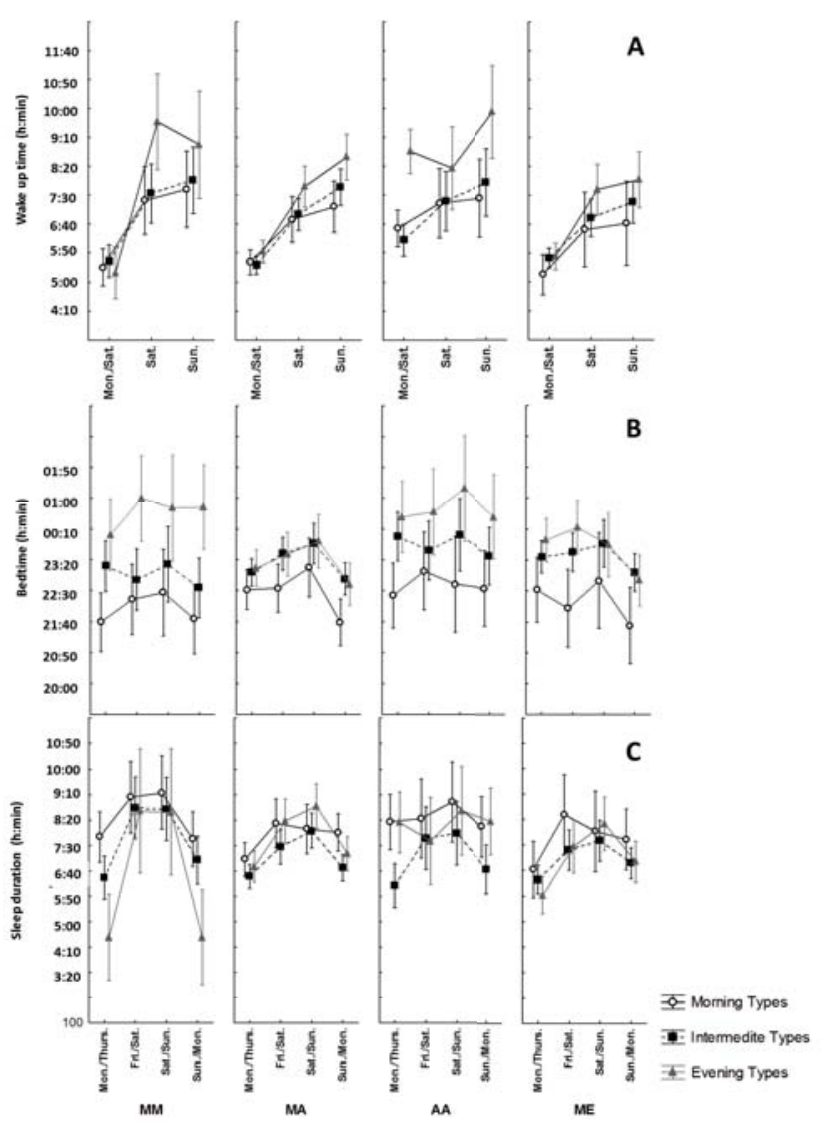

Figure 1. Wake Up Time (A), Bedtime (B), and Sleep Duration (C) in the Teachers During the Week and Weekend According to Work Group Schedule and Chronotype. GLM, $p<0.05$ - (Unequal N HSD test)

All teachers wake up later on weekends (Saturday and Sunday $-F_{(2,230)}=17.53 ; p<0.05-$ Figure $1 \mathrm{~A}$ ), and the MA, $\mathrm{AA}$, and $\mathrm{ME}$ groups reported waking up by themselves more frequently, whereas teachers of MM group reported more someone calling them (Chi-Square, $p<0.008$ ). The time of wake up was associated to domestic chores and not feeling sleepy (Chi-square - Figure 3B and 4B). Moreover, the evening types showed later wake up times than morning and intermediate types on the weekend, $F_{(2,115)}=12.61 ; p<0.05$ (Figure 1A). This difference was observed only on weekdays for teachers from the AA group (Figure 1A).

The bedtimes did not differ among working groups, $F_{(3 \text {, }}$ 116) $2.03 ; p>0.05$ (Figure 1B). However, the morning types showed earlier bedtimes than the others, $F_{(2,116)}=18.42 ; p<$ 0.05 (Figure 1B). The work schedule was the main reason reported by teachers of ME groups to justify their bedtime on weekdays and less reported by teachers of the AA group (Figure $3 C$ ). Furthermore, extra class activities, use of computer, and watching TV were reasons reported by teachers to explain the weekdays and weekend bedtimes. Nevertheless, during the weekdays the extra class activities held the majority of reports, while on weekends watching TV was the most reported (Chi-square - Figure 3C and 3D). 


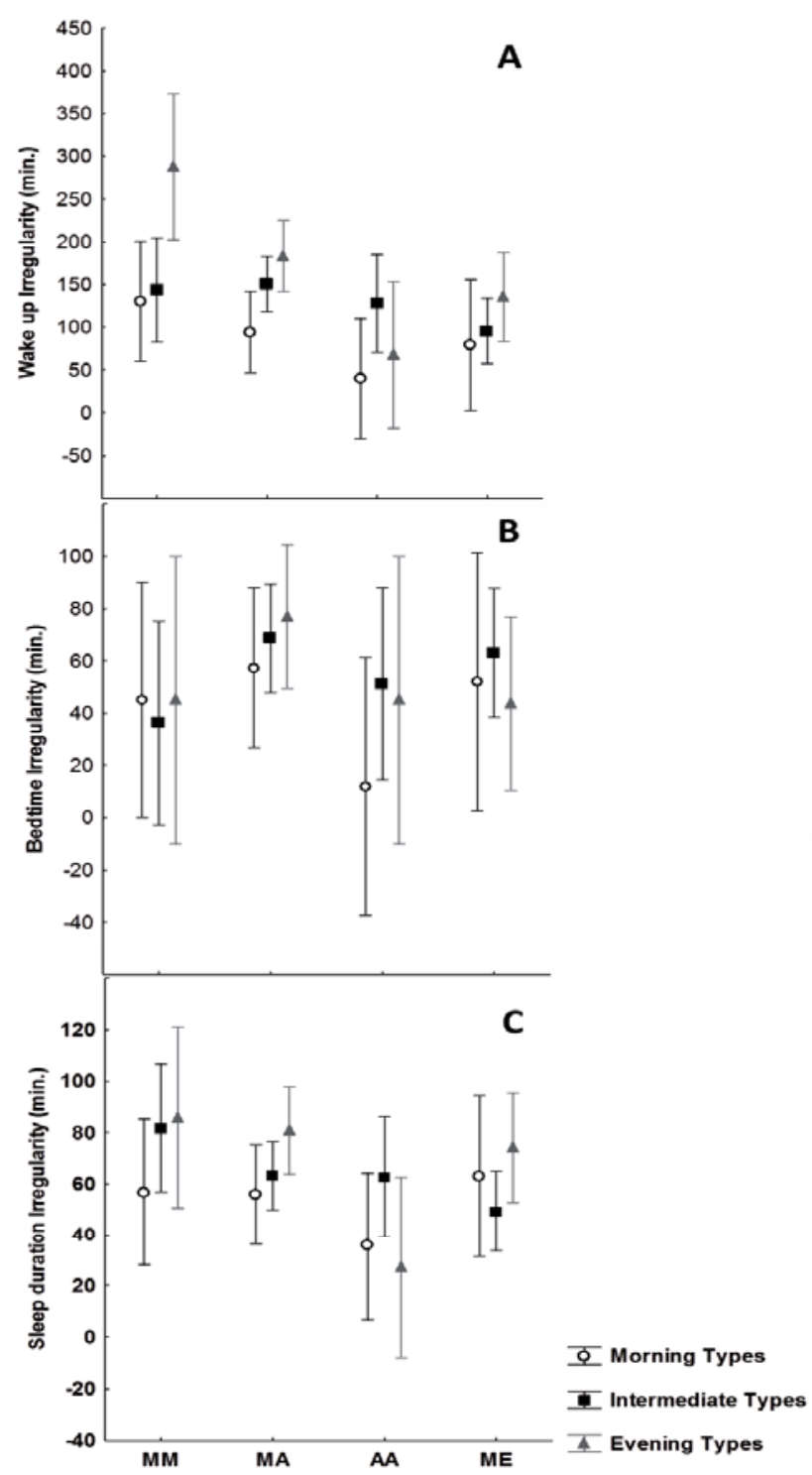

Figure 2. Irregularity of the Wake up Time (A), Bedtime (B), and Sleep Duration (C) in the Teachers According to Work Group Schedule and Chronotype. Anova, $p<0.05$ - (Unequal N HSD test)

Longer sleep duration on weekends (Friday/Saturday and Saturday/Sunday) in relation to weekdays (Monday/Thursday) was observed in intermediate and evening types from the MM, MA, and ME groups , $F_{(9,333)}=3.72 ; p<0.05$ (Figure $1 C)$. However, this difference has not been found in morning types regardless of work schedule, and in AA group regardless of chronotype (Figure $1 \mathrm{C}$ ). In relation to sleep duration irregularity, teachers from AA group were less irregular in sleep duration than teachers of the MM group , $F_{(3,119)}=2.79 ; p<$ 0.05 (Figure 2C).

The wake up time irregularity of the teachers from MM groups was higher than the AA group, $F_{(3,119)}=5.60 ; p<0.05$ (Figure 2A). Evening types showed higher wake up irregularity than morning types in the MM group , $F_{(2,119)}=5.78$; $p<$ 0.05 . The bedtime irregularity did not differ among working groups, $F_{(3,145)}=0.96 ; p>0.05$, neither among chronotypes (Anova, $p>0.05$ - Figure 2B).

The percentage of teachers classified with excessive daytime sleepiness was higher in MM and MA groups in relation to AA group (Chi-square, $p<0,008$, Figure $4 C$ ). Regarding the sleep quality, teachers from the MM group differed in relation to the others groups due to the higher percentage classified with poor sleep quality (Chi-square, $p>0,008$, Figure 4D). Although the mean scores from all groups did not differ , $F_{(3,114)}$ $=0.84 ; p>0.05$, all teachers showed means characteristic of poor sleep quality $(\mathrm{MM}=6.9 \pm 3.1, \mathrm{MA}=6.2 \pm 2.8, \mathrm{ME}=6.3$ $\pm 2.7, \mathrm{AA}=5,9 \pm 2,8)$.

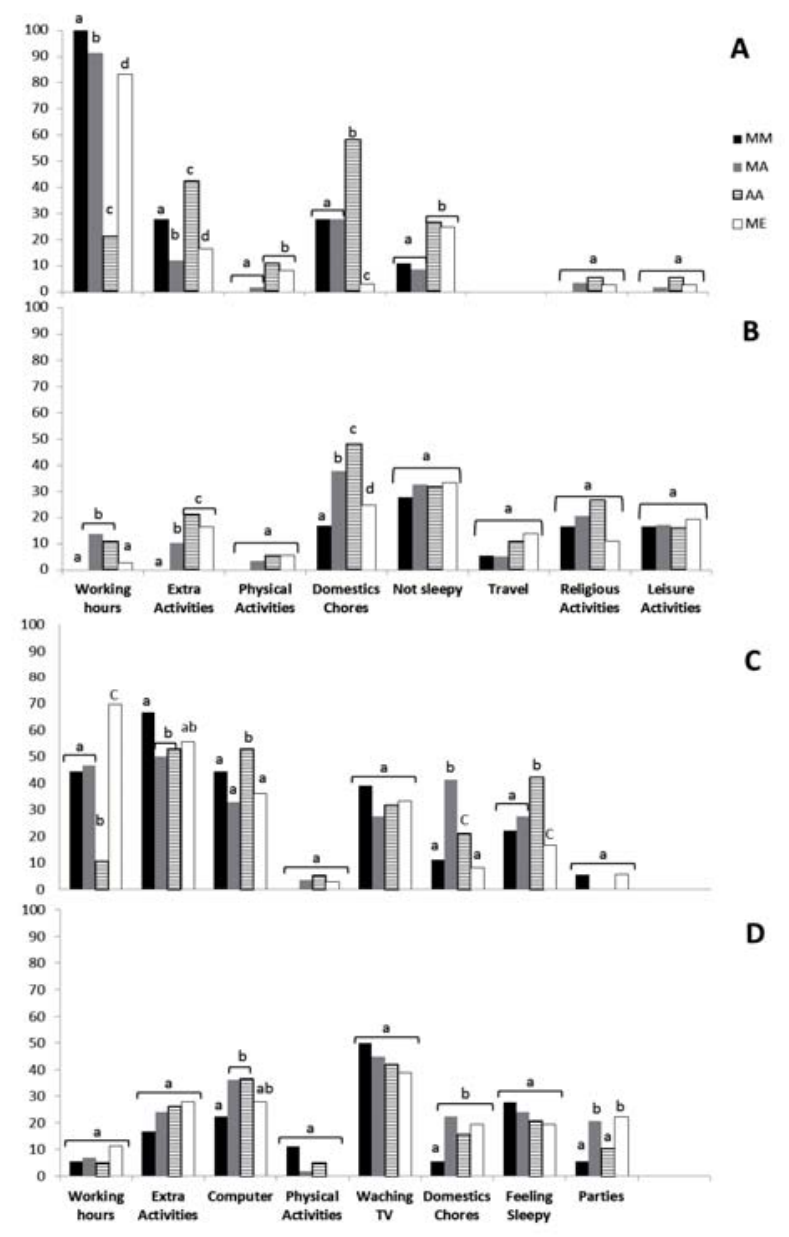

Figure 3: Reasons Given by Teachers for Wake up Time on Week (A) and Weekends (B), and for Bedtime on Week (C) and Weekends (D) According to Work Group Schedule. Different Letters Indicate Difference Statistically Significant and Equal Letters Indicate Similarities Between the Groups (Chi -square, $p<0.08$ ) 


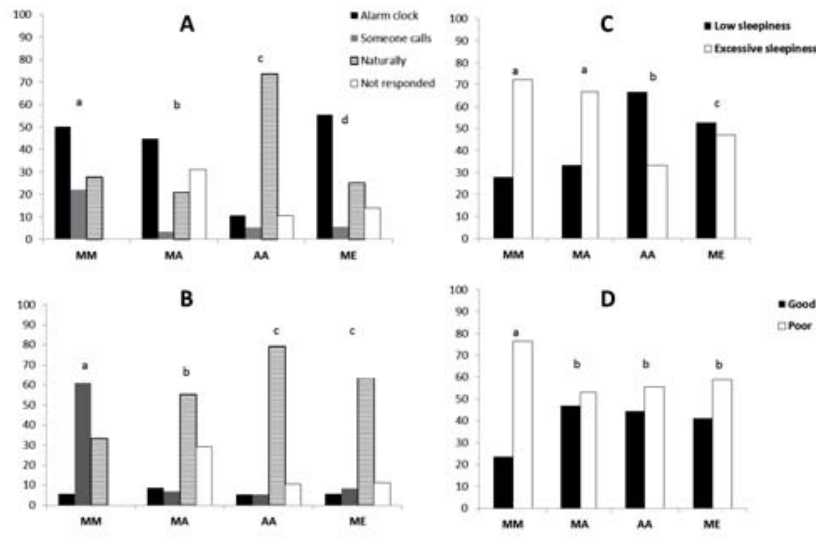

Figure 4. Percentages of teachers in Relation to the Way to Wake up in the Week (A) and on Weekends (B), Level of Diurnal Sleepiness (C) and Sleep Quality (D) According to Work Group Schedule. Different Letters Indicate Statistically Significant and Equal Letters Indicate Similarities Between the Groups (Chi-square, $p<0.08$ )

\section{Discussion}

The work schedule has influence on the SWC of the population which leads them to wake up earlier on weekdays in relation to the weekend, favoring wake up time irregularity (Groeger et al., 2004; Souza et al., 2012a; Monk et al., 2000; Webb, 1985). Similar results were observed in the teachers from this study that start work around 7:16 $\pm 0: 27 \mathrm{hr}$ and wake up earlier than those who begin their daily work by 13:06 \pm 0:15 hr regardless of chronotype, and more frequently report waking up at this time because of work schedule and use an alarm clock.

However, it is important to point out that the school start time between 7:00 to 7:30 hr seems to be a smaller challenge to the morning type teachers in relation to the evening ones, since the first have a lower mean of wake up time irregularity $(1: 28 \pm 0: 59 \mathrm{hr})$, sleep earlier on weekdays, and keep similar sleep duration between weekdays and the weekend. Kitamura and collaborators (2010) also detected some relation between morningness and lower sleep irregularity in adults. Besides the morning types, teachers who start working in the afternoon maintain the same sleep duration through weekdays to the weekend, regardless of the chronotype that confers lower sleep duration irregularity. Therefore, initiating labor after midday may bring some advantages to these professionals due to the absence of appointments very early in the morning, which could lead them to a later wake up time on weekdays.

On the other hand, the wake up time irregularity between the week and the weekend was more exacerbated among teachers of intermediate $(2: 09 \pm 1: 30 \mathrm{hr})$ and evening types $(2: 47 \pm 1: 52 \mathrm{hr})$ that work in the morning, showing that the challenge of attending work early in the morning can be even harder for these professionals. Moreover, these teachers increase their sleep duration on the weekend, possibly as compensation for the sleep deprivation resulting from the early work on weekdays. Similar results in workdays were observed in a previous study with high school teachers (Souza et al., 2012b) and in professionals of other areas (Groeger et al., 2004; Monk et al., 2000; Webb, 1985).

Different than expected, the bedtime of teachers who start work in the morning shift and finish it by evening hours did not diverge from other groups, despite that $70 \%$ of the teachers in this group justify their bedtime because of work schedule. This outcome may be the result of the influence of other teachers work characteristics that may contribute to teachers that finish their work before 12:00 hr or 18:00 hr to remain awake and not differ from those that finish work around 21:55 hr. For example, the reasons reported to justify their bedtime were the realization of extra activities related to class (prepare lessons and correct exams), which is routine for the teachers and the use of a PC. Besides, in search for better payment, they might be involved in another occupation or in a qualification course (specialization or master degree course).

Furthermore, extra class activities performed next to sleep time may be associated to computer use, being frequently done under artificial light. Light exposure strongly influences the onset of sleep (Mendoza \& Challet, 2009), because the light emitted by computer screens added to the artificial light of the domestic environment induces physiological alertness. Besides the delaying effect on sleep onset at night from light exposure, light exerts chronobiological effects on the next sleep-wake cycle, delaying the sleep onset the next night (Ivarsson, Anderson, Akerstedt, \& Lindblad, 2009; Wang \& Perry, 2006). Moreover, light inhibits melatonin secretion, a sleep -inducing hormone in humans, which contributes even more to sleep delay (Higuchi, Motohashi, Liu, \& Maeda, 2005).

The reduction of sleep and SWC irregularity are related to a high prevalence of daytime sleepiness, mood changes, and decreases in work performance (Dinges et al., 1997; Friedman et al., 1977; Johnson, Jung, Brow Weaver, \& Richards, 2014). Thus, the wake up time irregularity and the sleep reduction found among teachers that engage in class labor by morning might have contributed to the greater prevalence of excessive daytime sleepiness on $\mathrm{MM}$ and MA groups compared to teachers who start working in the afternoon (AA). However, this same result did not occur for teachers that work all three shifts (ME), which may be due to them being more resistant to these conditions or because of the method of sleepiness evaluation. The Epworth Sleepiness Scale (Johns, 1991) assesses sleepiness in day-to-day scenarios where the chance of napping is higher, such as watching TV and lying down after lunch. Considering the busy routine of these teachers, those situations may not be part of their routine, thus making it more difficult to evaluate their daily sleepiness subjectively. Therefore, the evaluation of sleepiness with objective instruments is necessary to test this hypothesis.

Regarding the quality of sleep, most teachers of the MM group had poor sleep quality which could explain the high incidence of daytime sleepiness in this group. However, this direct relationship was not observed in the MA and AA group which presented half of the teachers with poor sleep quality 
independent of the higher and lower percentage of excessive sleepiness observed in these groups, respectively. According to a study that evaluated 187 adults using the PSQI and the ESS in the methodology, these two parameters are weakly related (Buysse et al., 2008) which can explain the lack of relationship between excessive sleepiness and sleep quality in the teachers of this study.

The diurnal sleepiness may be associated with poor sleep quality, sleep deprivation (Akerstedt, Anund, \& Axelsson, 2014), and SWC irregularity in shift work (Akerstedt \& Wright, 2009). As previously discussed the group MM that presented sleep reduction on weekdays presented a high percentage of teachers with excessive sleepiness. Sleep quality can be affected by countless daily habits performed before the onset of sleep, such as caffeine consumption (Shilo et al., 2002), nicotine (Conway et al., 2008), and other environmental factors (lighting and noises). Therefore, it is a multifactorial influence variable, which may have limited evaluation of differences in sleep pattern due to the work schedule.

Nevertheless, it is important to highlight that the mean scores from IQSP of the teachers who work in the morning $(\mathrm{MM}=6.9 \pm 3.1, \mathrm{MA}=6.2 \pm 2.8, \mathrm{ME}=6.3 \pm 2.7)$ are similar to the scores seen for shift workers $(6.9 \pm 3.3)$ using the same assessment instrument (Almondes \& Araújo, 2011). As reported in a previous study (Souza et al., 2012b), this outcome is a strong concern since shift work is nowadays considered a risk factor for cancer development (Hansen, 2005; Straif et al., 2007; Viswanathan, Hankinson, \& Schernhammer, 2007), among other health problems.

Despite the similarity in the proportion between the individuals with poor and good sleep quality in two of the three groups who start work in the morning, we can conclude that school start time around 7:00 hr negatively influences sleep habits. This statement is based mainly on the MM and AA groups that have teachers with the same conditions, such as, teaching only one shift, workload, distribution of gender and chronotype, teaching only at one public school and the same sample size, and those groups differ only with respect to work schedule. Therefore considering these two groups, the work which starts in the afternoon can promote better sleep and wakefulness conditions. However, more studies can be made to evaluate if this schedule can contribute to a better work performance.

Despite the continuous production of some section from the so called 24-hour, many others sectors of work in Brazil start functioning after 8:00 hr. Nevertheless, schools start classes around 7:00 hr forcing students, teachers, and other school staff to wake up even earlier than the general population. The differential time for school start time and its consequences on sleep habits and academic performance of adolescents has been debated and assessed all around the world, and some studies show the benefit brought by delaying the school start by 1 hour. Among these benefits, the students with later wake up times favors the increase of sleep duration in the week, reduction of daytime sleepiness and fatigue, and an improvement in academic performance (Onyper, Thacher, Gilbert, \&
Gradess, 2012; Owens, Belon, \& Moss, 2010). However, the alteration of school schedules is a complex task, as it involves changes in the dynamics of families of students, school employees, and teachers as much as the work dynamics of the last ones. Therefore, these difficulties can be overcome with proper planning and the appliance of educative policies that promote awareness of the main people involved in the change process.

Added to that, the teaching professional faces many other challenges that are intimately related to health issues (Landini, 2007) and drop in education quality, such as: 1) extensive workload (Decor et al., 2004) to improve financial income (Reis, Araújo, Carvalho, Barbalho, \& Silva, 2006); 2) time spent on extra activities related to the teaching occupation (class planning, exam correcting) that increase the workload even more (Gasparini et al., 2006; Jardim, Barreto, \& Assunção, 2007); 3) the pursuit for professional qualification through continuous qualification programs (Jardim et al., 2007); 4) poor teaching infrastructure (Alves et al., 2009); 5) constant struggle for better salary; 6) increase of violence inside the school environment (Gasparini et al., 2006); all related to occupational stress (Bauer et al., 2007; Reis et al., 2006).

Therefore, it is important to assess other factors that may exert influence on the sleep pattern and quality of basic education for teachers, such as the time spent on class preparation and study, continuous qualification programs, practice of another occupation, stress evaluation and gender that may be contributing to the sleep problems of those teachers. At the same time, it is essential to estimate the consequences of sleep reduction in the week and the sleep/wake irregularity for the teacher's health and class performance.

Therefore, the discussion about school start times originally proposed for adolescents needs to be magnified to teachers, contributing to improvement of sleep habits and life quality in the school environment. This involves the participation not only of students and teachers, but the school staff, the families, and the development of public policies. In this sense, the results of research developed in a school setting are essential to underlie the debate about the temporal challenge often confronted by adolescents and also observed in the teachers in this study.

\section{Acknowledgments}

Special thanks are given to the teachers who participated in this research and to the members of the schools. We also thank the students Galileu Rodrigues Borges and Fernanda Fernandes Kolodiuk for their contribution in data collection and analysis and to Dr. Wallissen Tadashi Hattori and Dra. Alícia Cabral for suggestions to this study. We acknowledge the financial support from the Conselho Nacional de Desenvolvimento Científico e Tecnológico

(CNPq) and the Universidade Federal do Rio Grande do Norte. 


\section{References}

Akerstedt, T., \& Wright, K. P. (2009). Sleep loss and fadige in shift work and shift work disorder. Sleep Medicine Clinics, 4(2), 257-271. doi: 10.1016/j. jsmc.2009.03.001

Akerstedt, T., Anund, A., \& Axelsson. (2014). Subjective sleepiness is a sensitive indicator of insuficiente sleep and impaired waking function. Journal of Sleep Research, 23(3), 242-254. doi: 10.1111/jsr.12158

Almondes, K. M., \& Araújo, J. F. (2011). Sleep quality and daily lifestyle regularity in workers with different working hours. Biological Rhythm Research, 42(3), 231-245. doi:10.1080/09291016.2010.509480

Alves, L. A., Robazzi, M. L. C. C., Marziale, M. H. P., Felippe, A. C. N., \& Romano, C. C. (2009). Alterações da saúde e a voz do professor, uma questão de saúde do trabalhador. Revista Latino Americana de Enfermagem, 17(4), 566-572. doi: 10.1590/S0104-11692009000400020

Bauer, J., Unterbrink, T., Hack, A., Pfeifer, R., Buhl-Griebhaber, V., Müler, U., ... Wirsching, M. (2007). Working conditions, adverse events and mental health problems in a sample of 949 German teachers. International Archives of Occupational and Environmental Health, 80(5), 442-449. doi: 10.1007/s00420-007-0170-7

Benedito-Silva, A. A., Menna-Barreto, L., Marques, N., \& Tenreiro, S. (1990). A self-assessment for the determination of morningness-eveningness types in Brazil. In D. J. Hayes, J. E. Pauli, \& R. J. Reiter (Eds.), Chronobiology: Its role in clinical medicine, general biology and agriculture (pp. 89-98). Part B. New York: Wiley Liss.

Bussey, D. J., Reynolds, C. F., Monk, T. H., Berman, S. R., \& Kupfer, D. J. (1989). The Pittsburgh Sleep Quality Index: A new instrument for psychiatric practice and research. Psychiatry Research, 28(2), 193-213. doi: 10.1016/0165-1781(89)90047-4

Buysse, D. J., Hall, M. L., Strollo, P. J., Kamarck, T. W., Owens, J., Lee, L., ... Matthews, K. A. (2008). Relationships between the Pittsburgh Sleep Quality Index (PSQI), Epworth Sleepiness Scale (ESS), and Clinical/ Polysomnographic Measures in a Community Sample. Journal of Clinical Sleep Medicine, 4(6), 563-571. Retrieved from http://www.aasmnet.org/ jcsm/ViewAbstract.aspx?pid=27351

Conway, S. G., Roizenblatt, S. S., Palombini, L., Castro, L. S., Bittencourt, L. R. A., Silva, R. S., \& Tufik, S. (2008). Effect of smoking habits on sleep. Brazilian Journal of Medical and Biological Research, 41(8), 722-727. doi: 10.1590/S0100-879X2008000800014

Decor, N. S., Araújo, T. M., Reis, E. J. F. B., Porto, L. A., Carvalho, F. M., Silva, M. O., ... Andrade, J. M. (2004). Condições de trabalho e saúde dos professores da rede particular de ensino de Vitória da Conquista, Bahia, Brasil. Caderno de Saúde Pública do Rio de Janeiro, 20(1), 187-196. doi: 10.1590/S0102-311X2004000100035

Dinges, D. F., Pack, F., Williams, K., Gillen, K. A., Powell, J. W., Ott, ... Pack, A. I. (1997). Cumulative sleepiness, mood disturbance, and psychomotor vigilance performance decrements during a week of sleep restricted to 4-5 hours per night. Sleep, 13(20), 267-277.

Dorrian J., Tolley C., Lamond N., Heuvel C.V., Pincombe J., Rogers A.E., \& Drew D. (2008). Sleep and errors in a group of Australian hospital nurses at work and during the commute. Applied Ergonomics, 39(5), 605-613. doi: 10.1016/j.apergo.2008.01.012

Ferreira, L. P., Latorre, M. R. D. O., Giannini, S. P. P., Ghirardi, A. C. A. M., Karmann, D. F., Silva, E. E., \& Figueira, S. (2008). Influence of abusive vocal habits, hydration, mastication, and sleep in the occurrence of vocal symptoms in teachers. Journal of Voice, 24(1), 86-92. doi: 10.1016/j. jvoice.2008.06.001

Friedman, J., Globus, G., Huntley, A., Mullaney, P., Naitoh, P., \& Johnson, L. (1977). Performance and mood during and after gradual sleep reduction. Psychophysiology, 14(3), 245-250. doi: 10.1111/j.1469-8986.1977. tb01169.x

Gaspar, S., Moreno, C., \& Menna- Barreto, L. (1998). Os plantões médicos, o sono e a ritmicidade biológica. Revista da Associação Médica Brasileira, 44(3), 239-245. doi: 10.1590/S0104-42301998000300013

Gasparini, S. M., Barreto, S. M., \& Assunção, A. A. (2006). Prevalência de transtornos mentais comuns em professores da rede municipal de Belo
Horizonte, Minas Gerais, Brasil. Cadernos de Saúde Pública do Rio de Janeiro, 22(12), 2679-2691. doi: 10.1590/S0102-311X2006001200017

Groeger, J. A., Zijlstra, F. R. H., \& Dijk, D. J. (2004). Sleep quantity, sleep difficulties and their perceived consequences in a representative sample of some British adults. Journal of Sleep Research,13(4), 359-371. doi: 10.1111/j.1365-2869.2004.00418.x

Hansen, M., Janssen, I., Schiff, A., Zee, P. C., \& Dubocovich, M. L. (2005).The impact of school daily schedule on adolescent sleep. Pedriatics, 115(6), 1555-1561. doi: 10.1542/peds.2004-1649

Higuchi, S., Motohashi, Y., Liu, Y., \& Maeda, A. (2005). Effects of playing a computer game using a bright display on pre-sleep physiological variables, sleep latency, slow wave sleep and REM sleep. Journal of Sleep Research, 14(3), 267-273. doi: 10.1111/j.1365-2869.2005.00463.x

Horne, J. A., \& Osterberg, O. A. (1976). Self-assessment questionnaire to determine morningness-eveningness in human circadian rhythms. International Journal of Chronobiology, 4(2), 97-110.

Ivarsson, M., Anderson, M., Akerstedt, T., \& Lindblad, F. (2009). Playing a violent television game affects heart rate variability. Acta Paediatric, 98(1), 166-172. doi: 10.1111/j.1651-2227.2008.01096.x

Jardim, R., Barreto, S. M., \& Assunção, A. A. (2007). Condições de trabalho, qualidade de vida e disfonia entre docentes. Cadernos de Saúde Pública, 23(10), 2439-2461. doi: 10.1590/S0102-311X2007001000019

Johns, M. V. (1991). A new method for measuring daytime sleepiness: The Epworth Sleepiness Scale. Sleep, 14(6), 540-545. Retrieved from http:// www.journalsleep.org/ViewAbstract.aspx?pid=24884

Johnson, A., Jung, L., Brown, K. C., Weaver, M. T., \& Richards, K. C. (2014). Sleep deprivation and error in nurse who work the night shift. Journal of Nursing Administration, 44(1), 17-22. doi: 10.1097/ NNA.0000000000000016

Kitamura, S., Hida, A., Watanabe, M., Enomoto, M., Aritake-Okada, S., Moriguchi, Y., ... Mishima, K. (2010). Evening preference is related to the incidence of depressive states independent of sleep-wake conditions. Chronobiology International, 27(9-10), 1797-1812. doi: 10.3109/07420528.2010.516705

Landini, S. R. (2007). Professor, trabalho e saúde: As políticas educacionais, a materialidade histórica e as consequências para a saúde do trabalhadorprofessor. Colloquium Humanarum, 4(1), 08-21. doi: 10.5747/ch.2007. v04.n1

Mathias, A., Sanchez, R. P., \& Andrade, M. M. (2006). Incentivar hábitos de sono adequados: um desafio para os educadores. In S. Z. Pinho, \& J. R. C. Saglietti, Núcleo de ensino da Unesp (pp. 718-731). São Paulo: Universidade Estadual Paulista.

Mendoza, J., \& Challet, E. (2009). Brain clocks: From the suprachiasmatic nuclei to a cerebral network. The Neuroscientist, 15(5), 477-488. doi: $10.1177 / 1073858408327808$

Monk, T. H., Buysse, D. J., Rose, L. R., Hall, J. A., \& Kupfer, D. J. (2000). The sleep of healthy people-a diary study. Chronobiology International, 17(1), 49-60. doi: 10.1081/CBI-100101031

Nagai, M., Tsuchiya, K. J., Toulopoulou, T., \& Takei. N. (2007). Poor mental health associated with job dissatisfaction among school teachers in Japan. Journal Occupational Health, 49(6), 515-522. doi: http://dx.doi. org/10.1539\%2Fjoh.49.515

Onyper, S. V., Thacher, P. V., Gilbert, J. W., \& Gradess, S. G. (2012). Class start times, sleep, and academic performance in college: a path analysis. Chronobiology International, 29(3), 318-335. doi: 10.3109/07420528.2012.655868

Owens, J. A., Belon, K., \& Moss, P. (2010).Impact of delaying school start time on adolescent sleep, mood, and behavior. Archives of Pediatrics and Adolescent Medicine, 164(7), 608-614. doi:10.1001/archpediatrics.2010.96

Penteado, R. Z., \& Perreira, I. M. T. B. (2007). Qualidade de vida e saúde vocal de professores. Revista de Saúde Pública, 41(2), 236-243. doi: 10.1590/ S0034-89102007000200010 
Reis, E. J. F. B., Araújo, T. M., Carvalho, F. M., Barbalho, L., \& Silva, M. O. (2006). Docência e exaustão emocional. Educação \& Sociedade, 27(94), 229-253. doi: 10.1590/S0101-73302006000100011

Santos-Silva, R., Bittencourt, L. R. A., Pires, M. L. N., Mello, M. T., Taddei, J. A., Benedito-Silva, A. A., ... Tufik, S. (2010). Increasing trends of sleep complaints in the city of São Paulo, Brazil. Sleep Medicine, 11(6), 520-524. doi: 10.1016/j.sleep.2009.12.011

Shilo, L., Sabbah, H., Hadari, R., Kovatz, S., Weinberg, U., Dolev, S., ... Shenkman, L. (2002). The effects of coffee consumption on sleep and melatonin secretion. Sleep Medicine, 3(3), 271-273. doi: 10.1016/S13899457(02)00015-1

Soehner, A. M., Kennedy, K. S., \& Monk, T. H. (2011). Circadian preference and sleep-wake regularity: Associations with self-report sleep parameters in daytime-working adults. Chronobiology International, 28(9), 802-809. doi: 10.3109/07420528.2011.613137

Souza, J. C., Sousa, I. C., Maia, A. P. L., \& Azevedo, C. V. M. (2012a). Sleep patterns of teachers and adolescents who attend school in the morning. Biological Rhythm Research, 43(1), 65-72. doi: 10.1080/09291016.2011.638156

Souza, J. C., Sousa, I. C., Belísio, A. S., \& Azevedo, C. V. M. (2012b). Sleep habits, daytime sleepiness and sleep quality of high school teachers. Psychology \& Neuroscience, 5(2), 257-263. http://dx.doi.org/10.3922/j.psns.2012.2.17

Straif, K., Baan, R., Grosse, Y., Secretan, B., Ghissassi, E., Bouvard, ... Cogliano, V. (2007). Carcinogenicity of shift-work, painting, and fire-fighting. The Lancet Oncology, 8(12), 1065-1066. doi:10.1016/S1470-2045(07)70373-X

Taillard, J., Philip, P., \& Bioulac, B. (1999). Morningness/eveningness and the need for sleep. Journal of Sleep Research, 8(4), 291-295. doi: 10.1046/j.1365-2869.1999.00176.x

Vedovato, T. G., \& Monteiro, M. I. (2008). Perfil sociodemográfico e condições de saúde e trabalho dos professores de nove escolas estaduais paulistas. Revista da Escola de Enfermagem da USP, 42(2), 290-297. doi: 10.1590/ S0080-62342008000200012

Viswanathan, A. N., Hankinson, S. E., \& Schernhammer, E. S. (2007). Night shift work and the risk of endometrial cancer. Cancer Research, 67(21), 10618-10622. doi:10.1158/0008-5472.CAN-07-2485

Wang, X., \& Perry, A. C. (2006). Metabolic and physiologic responses to video game play in 7- to 10-year old boys. Archives of Pediatrics and Adolescent Medicine, 160(4), 411-155. doi:10.1001/archpedi.160.4.411

Weeb, W. B. (1985). Sleep in industrialized settings in the northern hemisphere. Psychological Reports, 57(2), 591-598. doi: 10.2466/pr0.1985.57.2.591

Wittmann, M., Dinich, J., Merrow, M., \& Roennenberg, T. (2006). Social jetlag: Misalignment of biological and social time. Chronobiology International, 23(1-2), 497-509. doi:10.1080/07420520500545979 
Jane Carla de Souza, Doctor's Degree in Psychobiology - Federal University of Rio Grande do Norte (UFRN), she is a substitute professor at Faculdade de Ciências da Saúde do Trairi-Federal University of Rio Grande do Norte (UFRN). E-mail: janebrjp@hotmail.com

Sabinne Danielle Galina, Graduate Degree in Biological Sciences - Federal University of Rio Grande do Norte (UFRN). E-mail: sabinneg@hotmail.com

Jônathas Cleiton Florêncio de Almeida, Attending the Graduate Degree in Biological Sciences at the Federal University of Rio Grande do Norte (UFRN). E-mail: koboldd@gmail.com

Ivanise Cortez de Sousa, Doctor's Degree in Psychobiology -Federal University of Rio Grande do Norte (UFRN), She is a professor at Department of Physiology -Federal University of Rio Grande do Norte/ UFRN. E-mail: ivanise@cb.ufrn.br

Carolina Virginia Macêdo de Azevedo, Doctor's Degree in Neurociences and Behavior /Psychology University of São Paulo (USP), is a full professor at the Department of Philosophy - Federal University of Rio Grande do Norte (UFRN). Address: Departamento de Fisiologia, Universidade Federal do Rio Grande do Norte. P.O.box: 1511. CEP 59078-970 Natal/RN. Phone: 84 3215-3409. Fax: 84 3211-9206. E-mail:carolina@cb.ufrn.br and/or carolinavmazevedo@gmail.com 